\title{
Enfermedades crónicas y
}

cavipsto

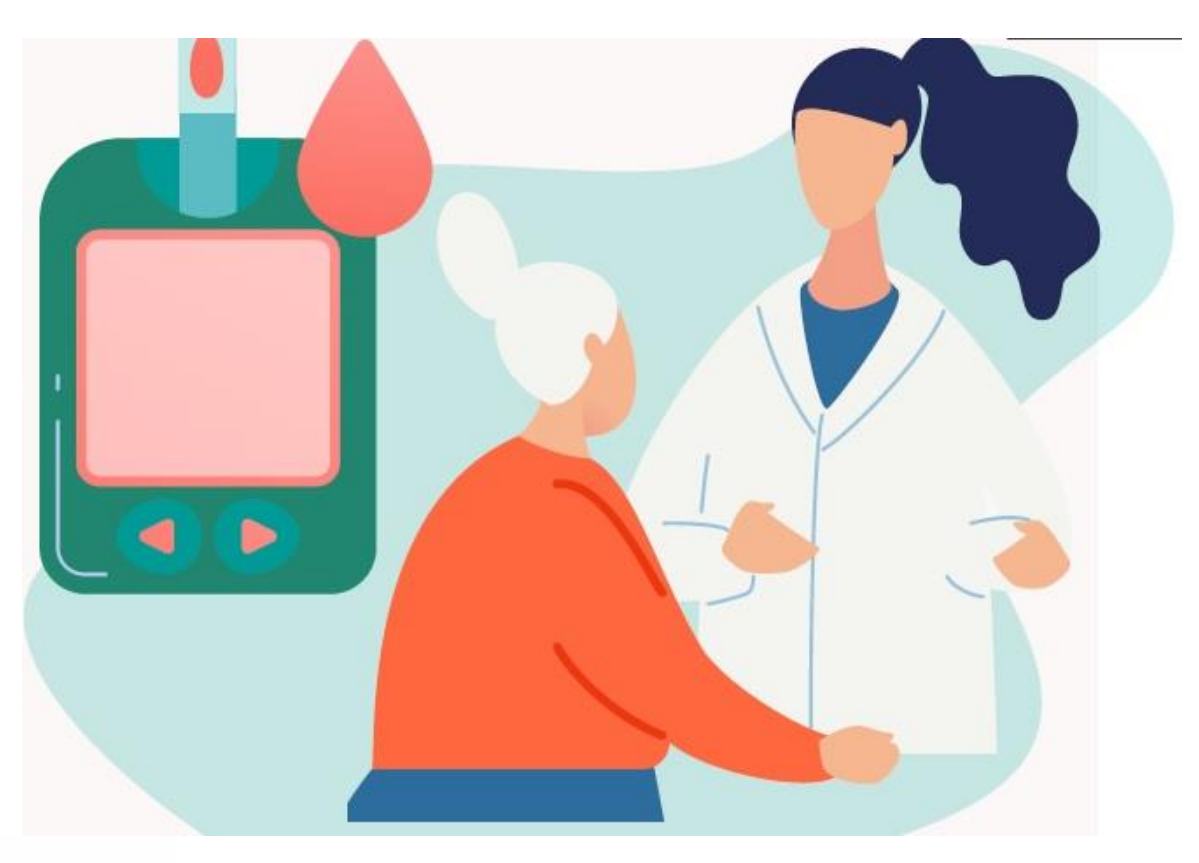

$\int p$

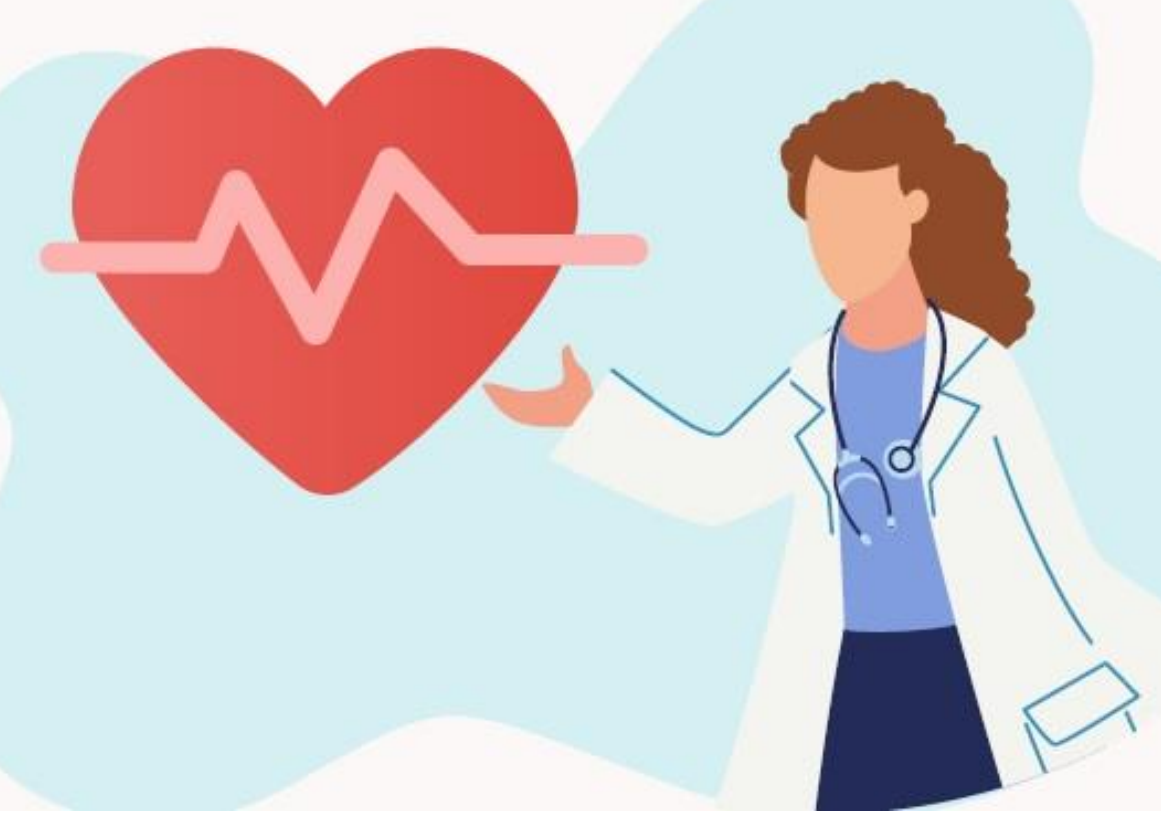

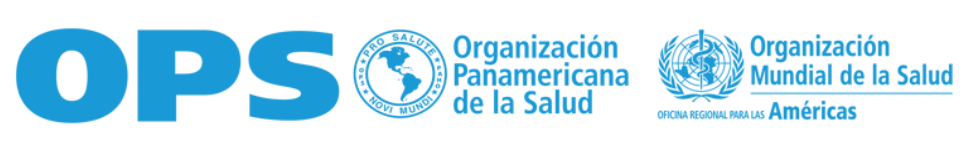




\section{Ministerio de Salud Pública Secretaría de Derechos Humanos CORAPE \\ Organización Panamericana de la Salud \\ Organización Mundial de la Salud




\section{Pónganse cómodos/as, bienvenidas/os.}


"Nunca hemos visto una relación tan letal entre una enfermedad infecciosa y las enfermedades no transmisibles. Algunos de los datos son realmente alarmantes. Especialmente para nuestra región, donde las ENT están extendidas ampliamente. Existe relación mortal, no vista con otras infeccionesi

\section{Dra. Carissa Etienne, Directora OPS/OMS}




\title{
COVIDS19
}

\author{
Dra. Sonia Quezada \\ Asesora internacional \\ OPS/OMS
}

OPSC 


\section{Enfermedades crónicas}

Se tiene más riesgo de contraer una forma grave de COVID-19 si se padece una enfermedad no transmisible o afecciones previas como:

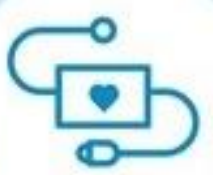

tensión arterial alta

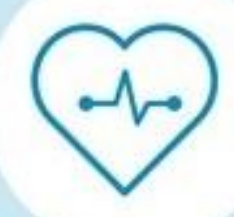

accidente cerebrovascular

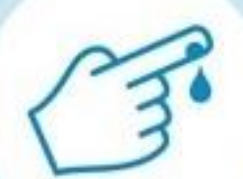

diabetes

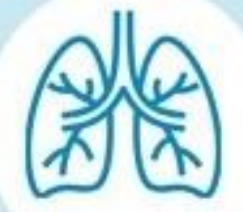

afecciones

respiratorias crónicas

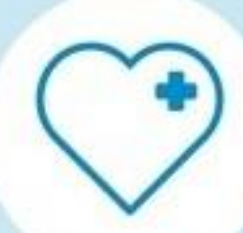

cardiopatías

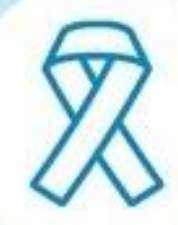

cánceres 


\section{Datos importantes}

- En China se comprobó que el $\mathbf{2 8 \%}$ de personas con cáncer que se han contagiado con COVID murieron comparados con el resto de la población que alcanza a un

2\%. A.L tiene 1200.000 de personas que viven con cáncer.

- Las personas con diabetes tienen dos veces mayor probabilidad para contraer una enfermedad severa o morir x COVID-19. En A.L hay 62 millones de personas con Diabetes.

- A.L 1 de 4 personas corren el riesgo de contraer una enfermedad severa o morir por este virus por que tiene ENT subyacentes. 


\section{No se ha ganado la batalla al COVID-19}

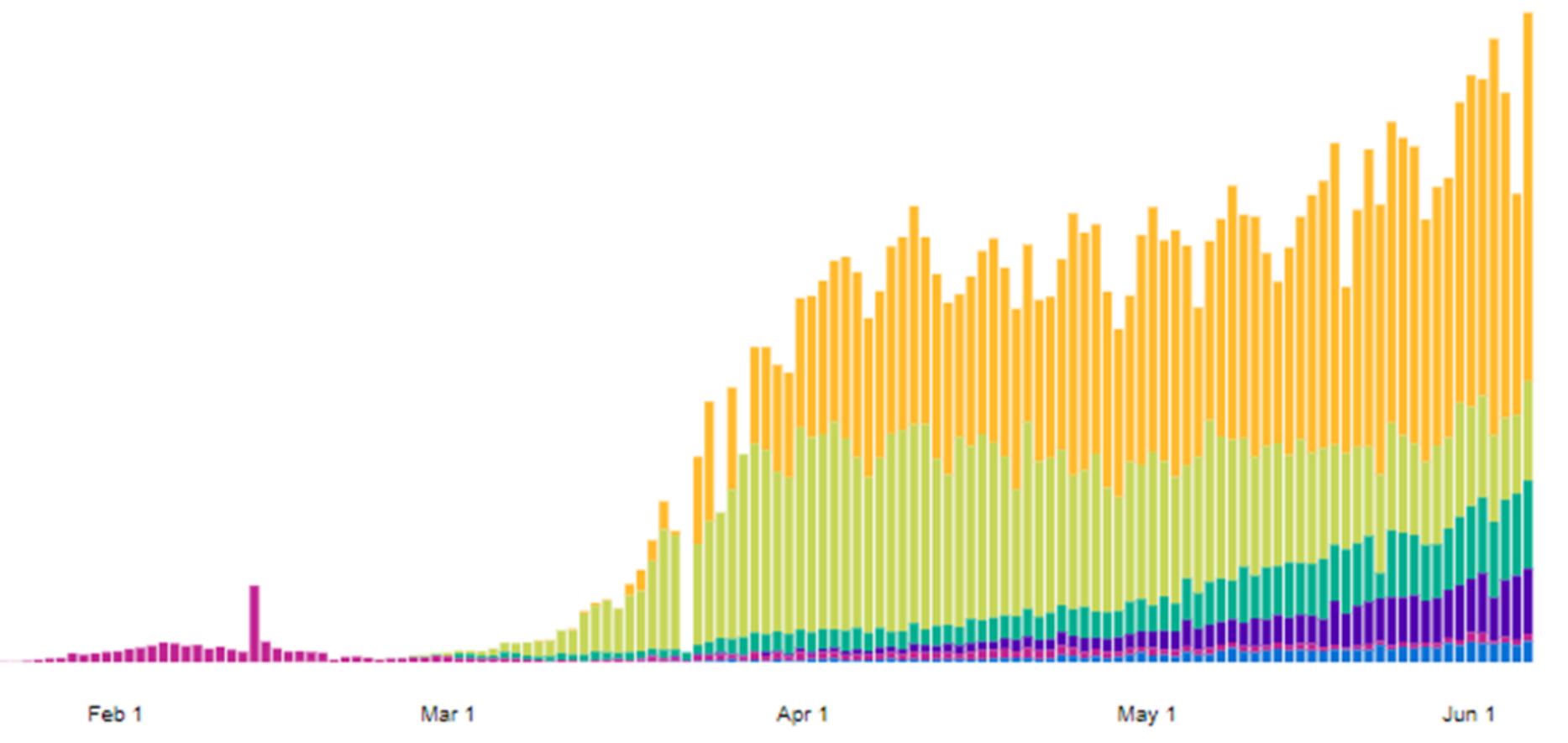

Amnérica

Europa

Este Mediterraneo

Asia

Africa 


\section{¿Cómo identificamos el riesgo en nuestras zonas?}

- ¿Está la epidemia bajo control?

- ¿Tienen los servicios de salud la capacidad de atender a los pacientes?

- ¿El sistema de vigilancia tiene la capacidad de detectar casos y contactos nuevos?
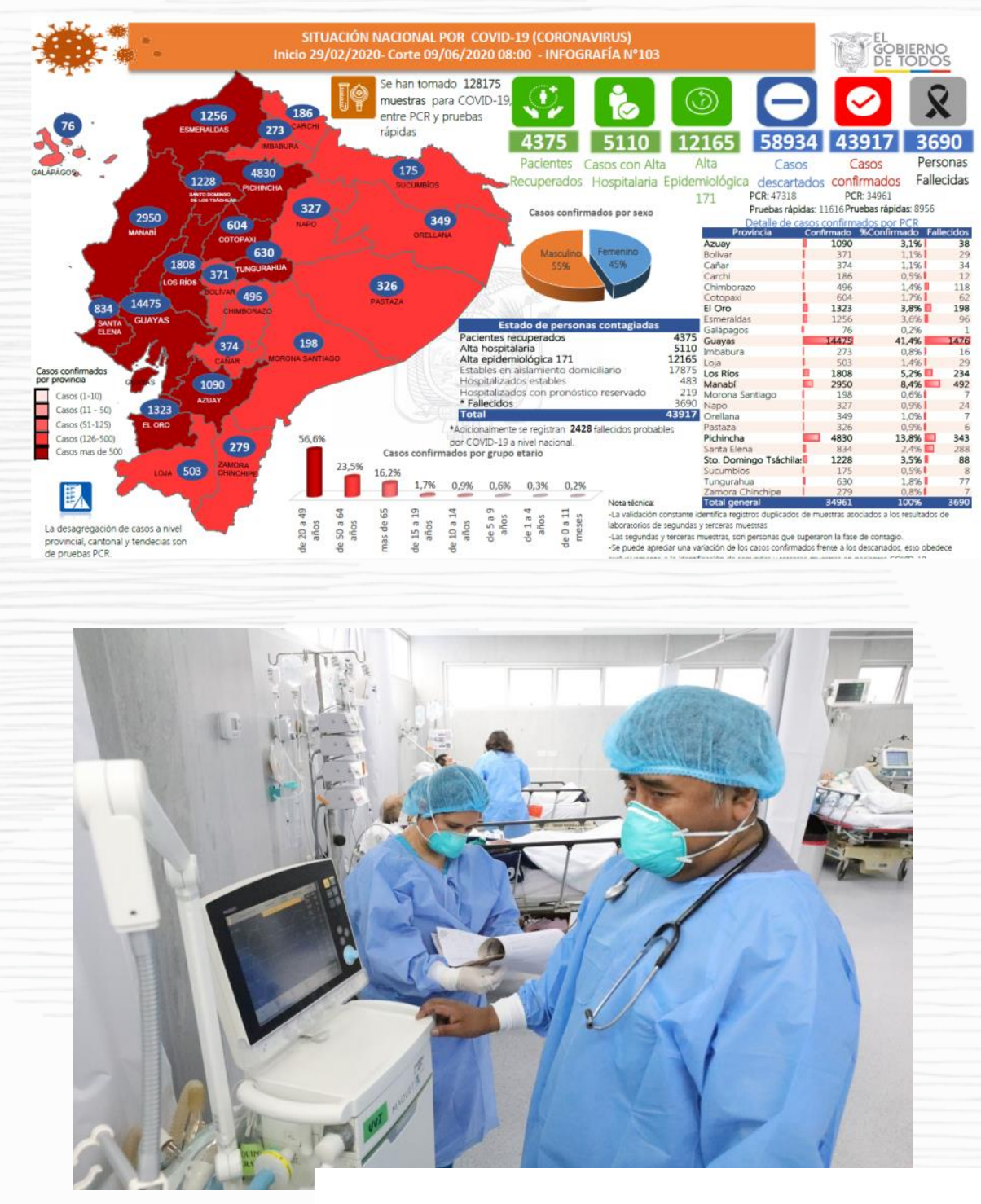

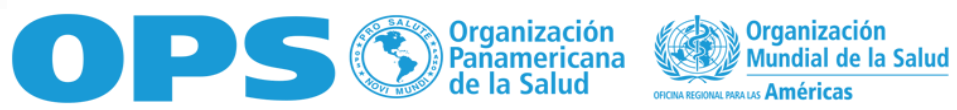




\section{¿Cómo se transmite el COVID-19?}

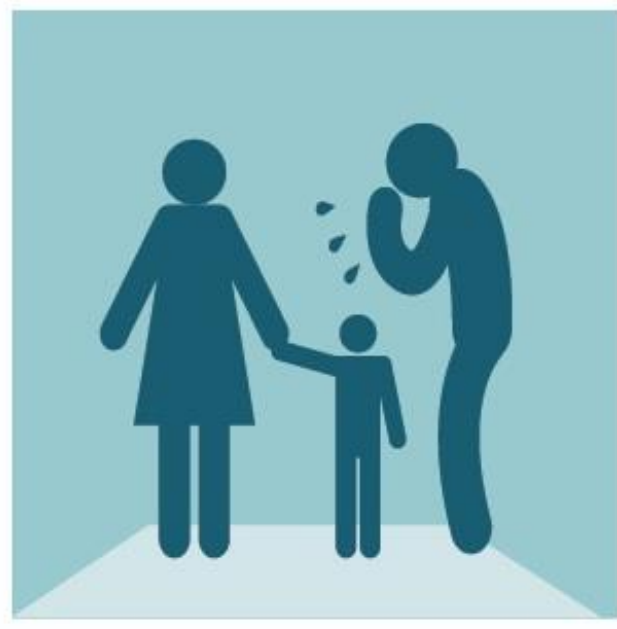

Por contacto personal cercano con una persona infectada 0 a través de personas infectadas al toser 0 estornudar.

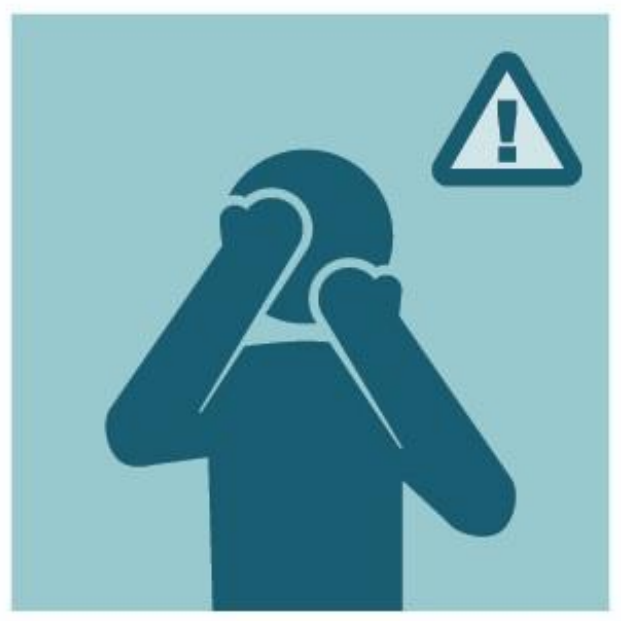

Al tocar objetos o superficies contaminadas y luego tocarse la boca, la nariz o los ojos. 


\section{Como se daria la trasmisión?}

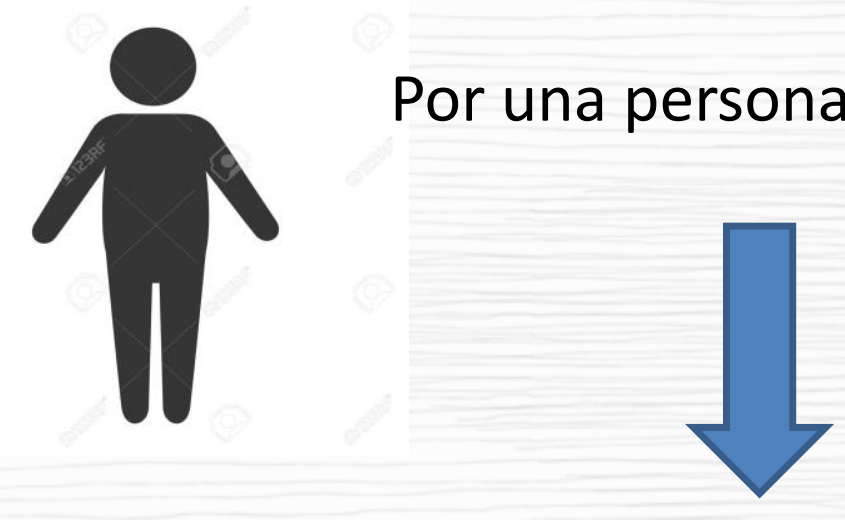

Quiere decir que cada persona infectada puede infectar entre 2 y 3 personas

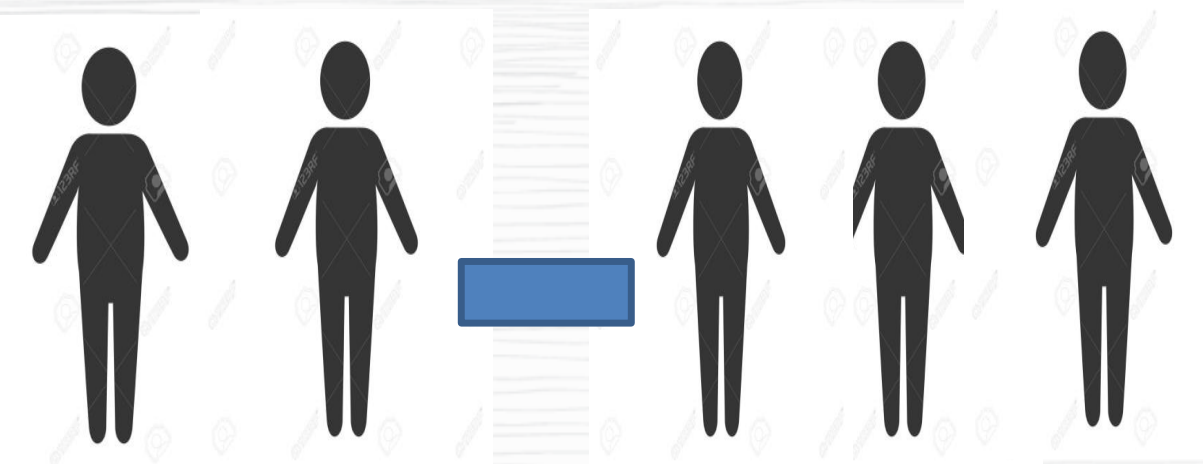

Para controlar la epidemia, se necesita disminuir por debajo de 1 


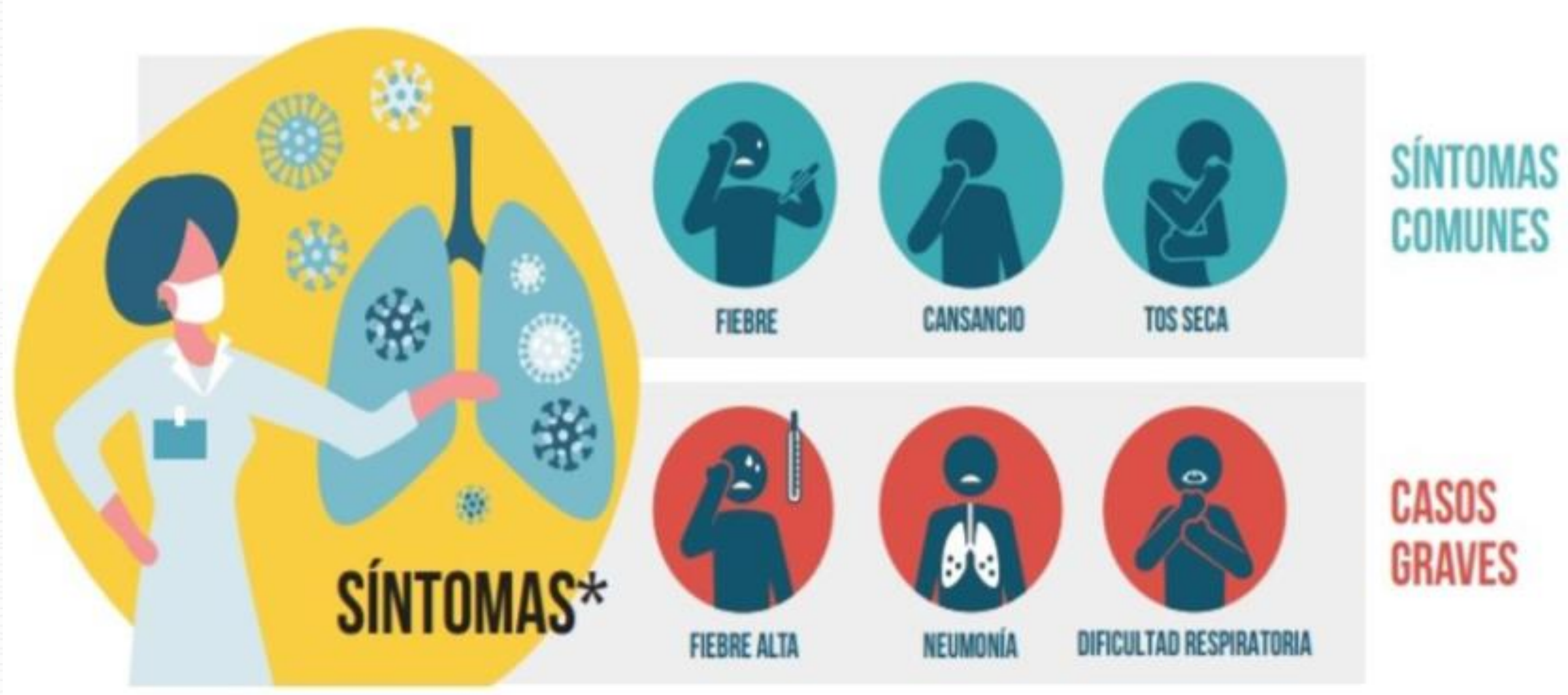

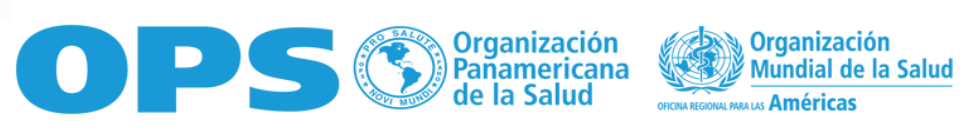




\section{¿Cómo prevenir el COVID-19?}

La mejor prevención es quedarse en casa.

Las familias y toda la sociedad debe proteger a las personas con enfermedades crónicas.
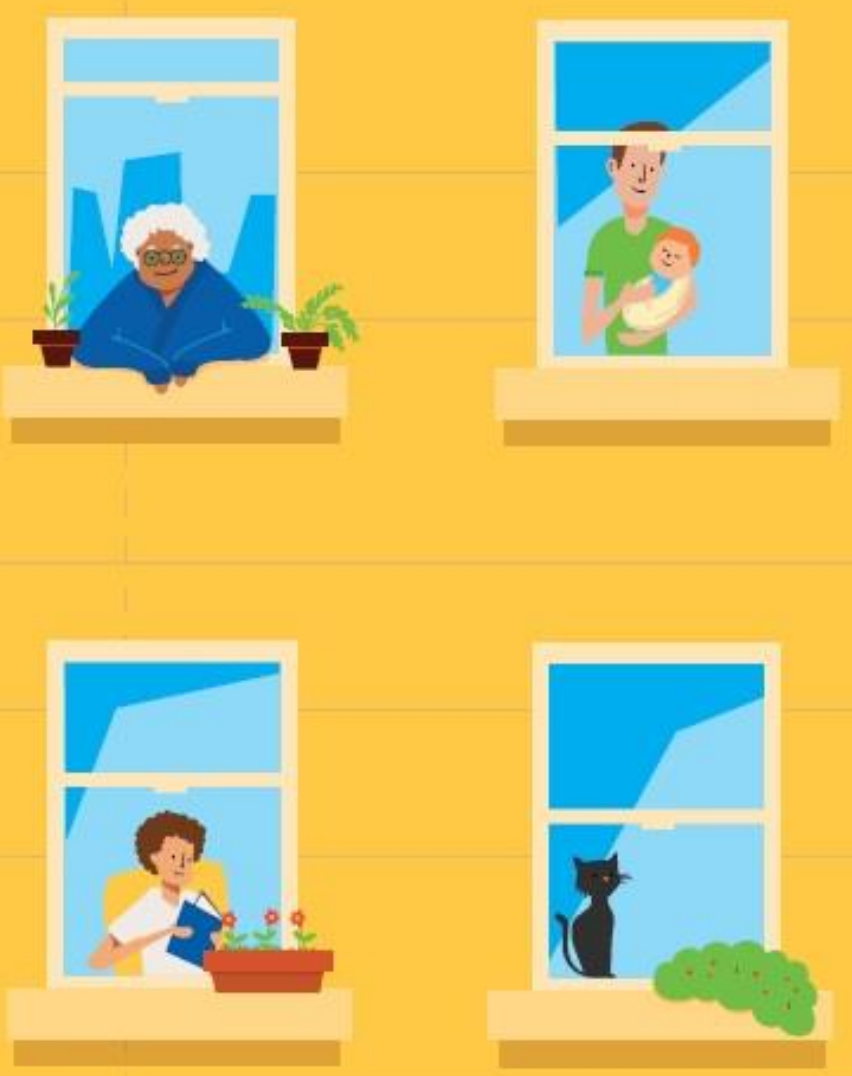

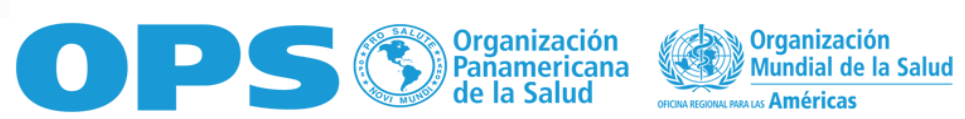




\section{Alimentación saludable}

Consume diversos tipos de alimentos

Come abundantes vegetales, legumbres y frutas

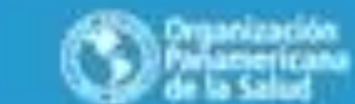

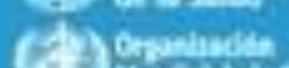

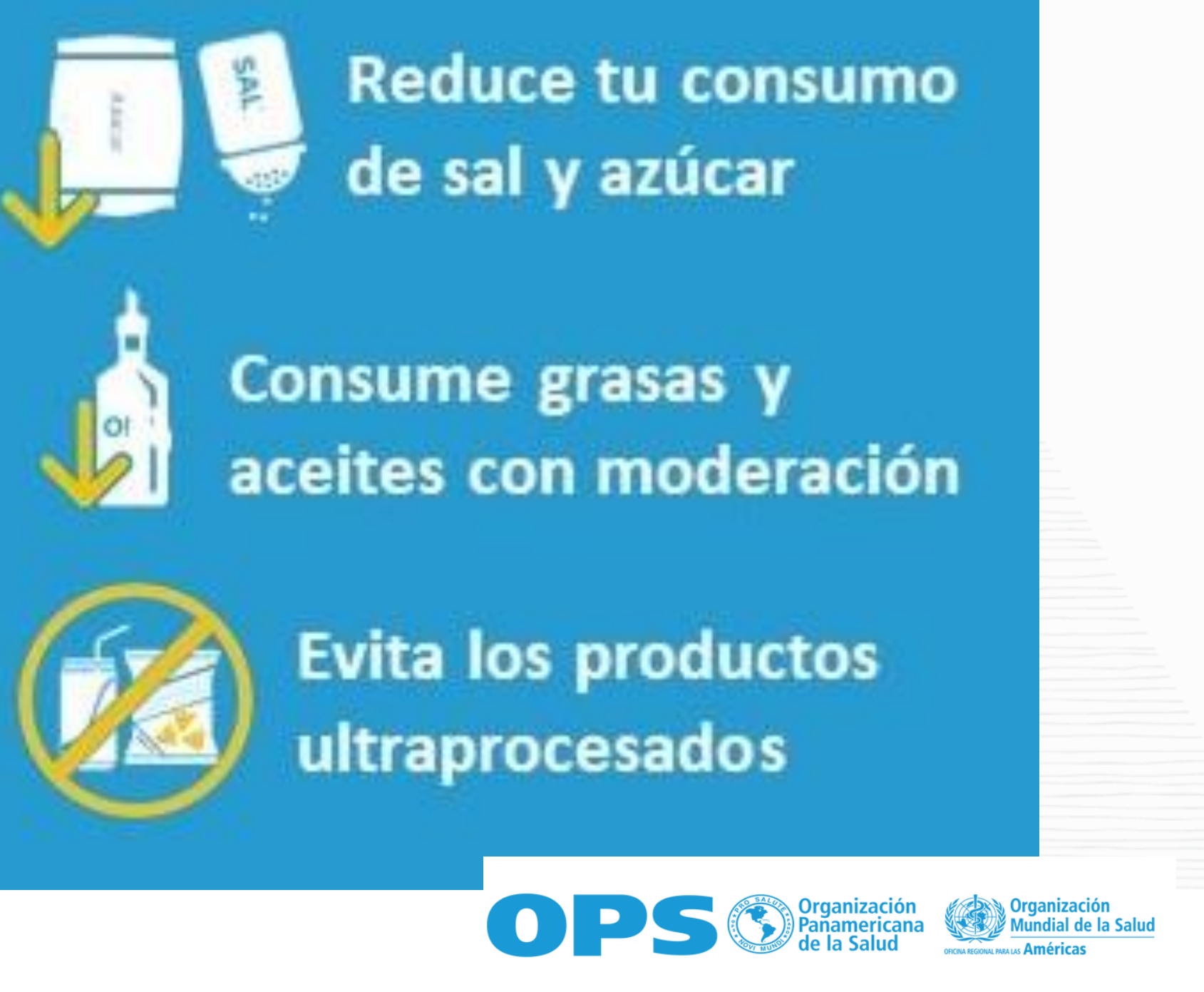



AL DÍA DISMINUYE EL RIESGO DE MUERTE POR ENFERMEDADES COMO LA DIABETES.

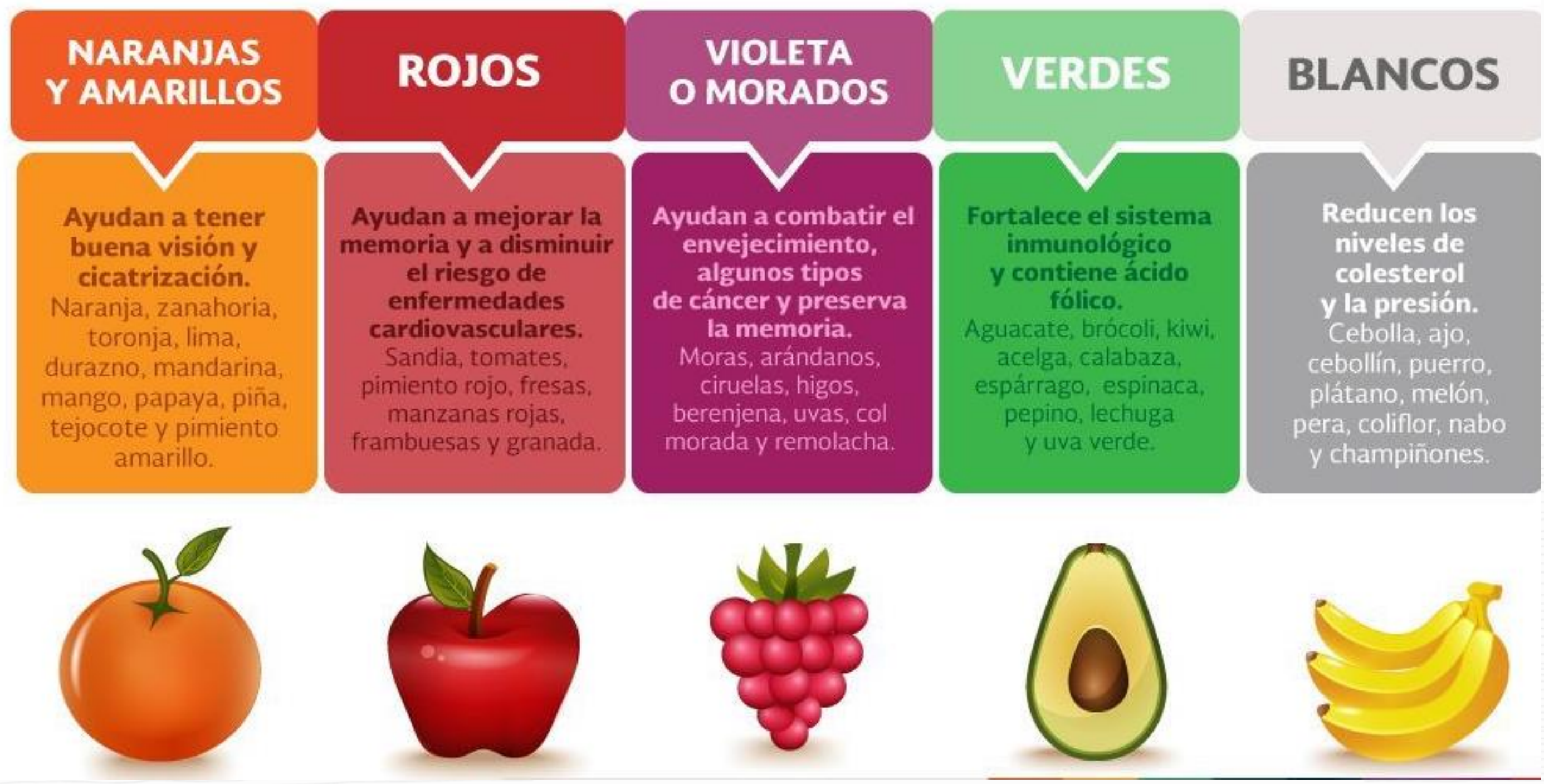




\section{Consumo de grasas trans}

La OMS recomienda que la ingesta total de grasas trans se limite a menos del $1 \%$ de la ingesta energética total, lo que se traduce en menos de 2,2 gramos por día como parte de una dieta de 2000 calorías

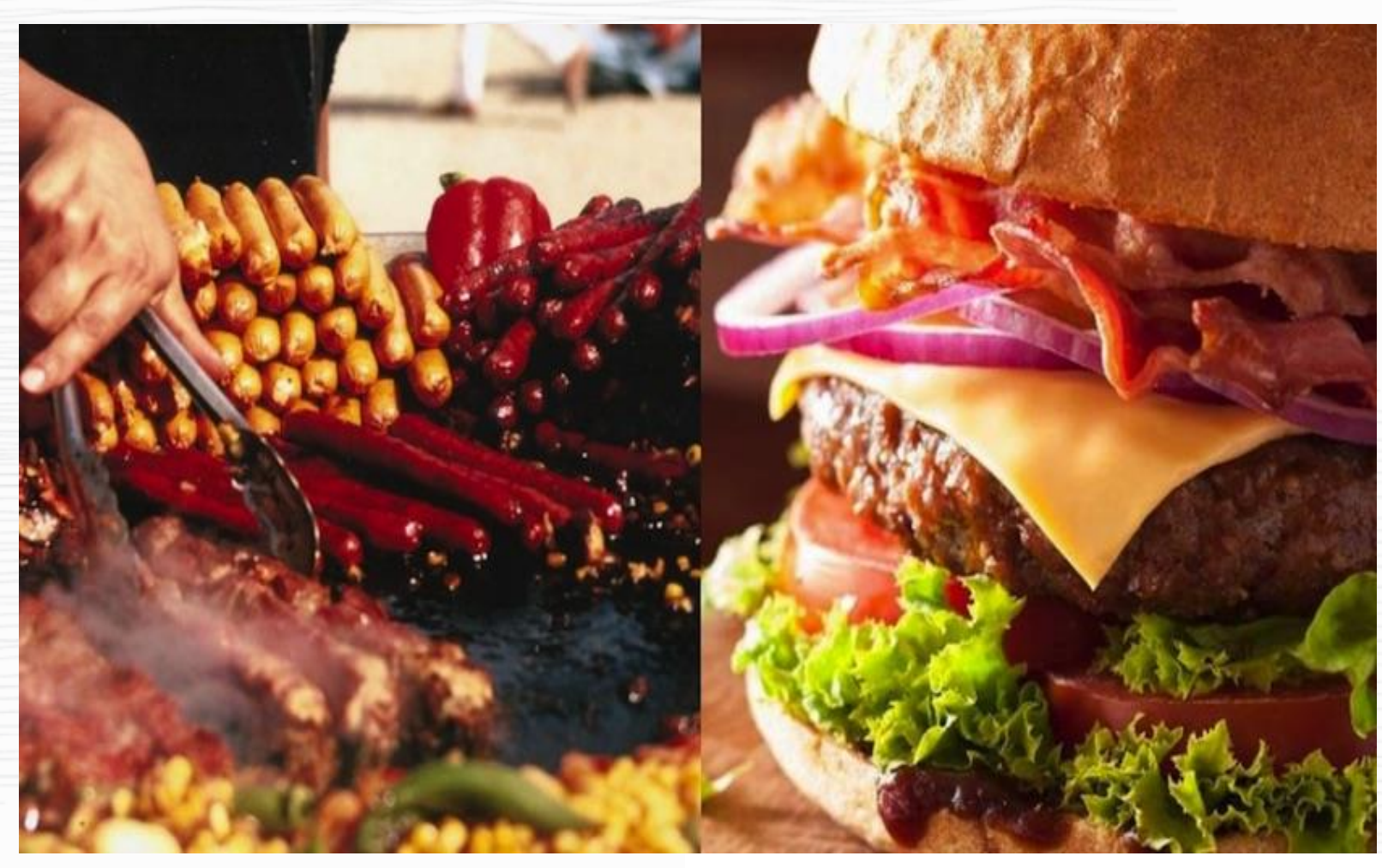




\section{Mantenerse activo}

- Ponga música y camine rápidamente la casa o subir y bajar gradas por 10 a 15 minutos, 2-3 veces al día

- Baila con tu música favorita

- Salte cuerda (si no tiene problemas articulares)

- Utiliza la bicicleta para ir de un lugar a otro

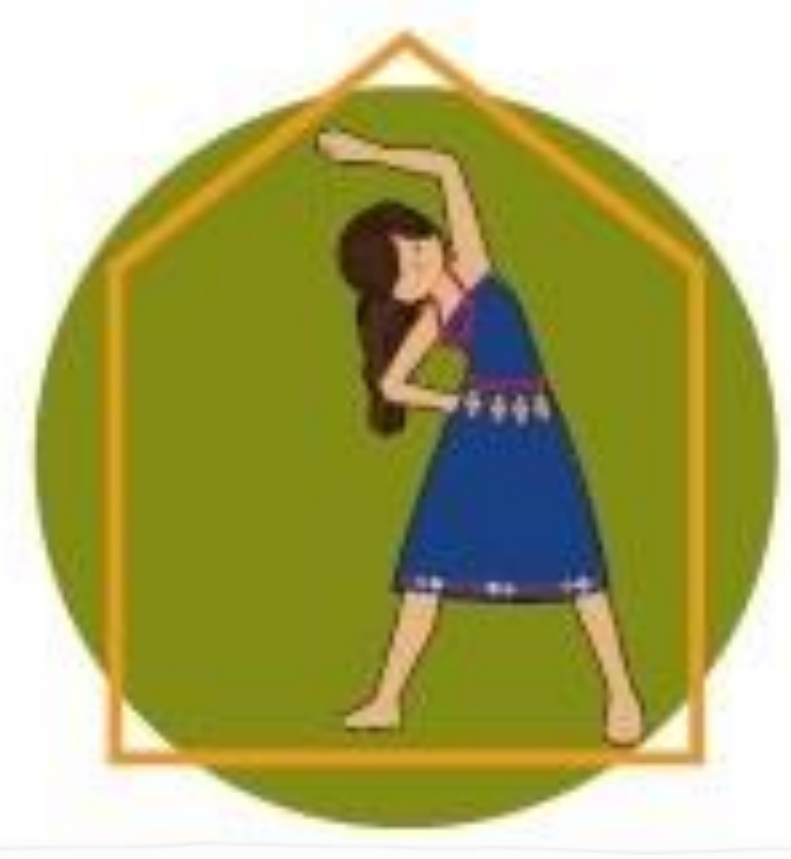


¿sabes qué es la actividad física?

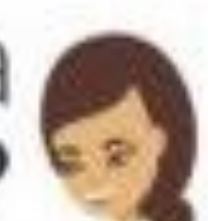

Eualiquic movimiento corporal cutisleve de energia. i
Lantensidad de la actividad fisica

variasegun las perscones

Adultos mayores

...... de 65 años:

Tan sólo 30 minutos de actividad física evitan la manifestación de:
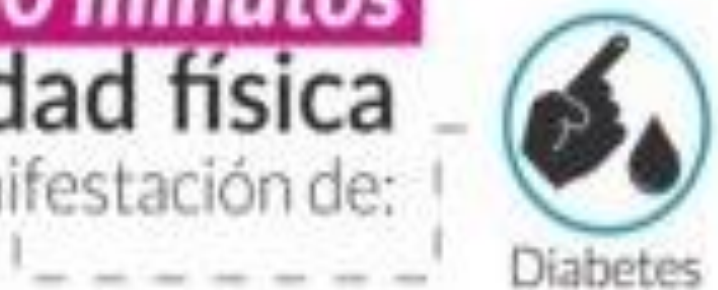

Diabetes

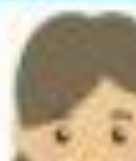

7.

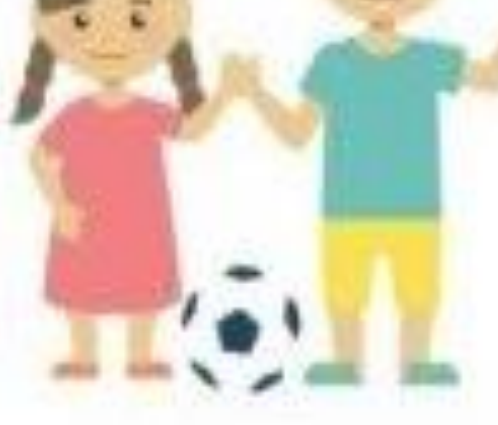

Adultos de entre 18 años y 64 años:

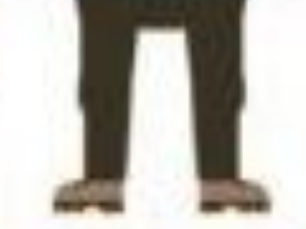
150 minutos semimats.
(1)

Osteoporosis
Niños y jóvenes de entre 5 a 17 años: sominutosac as

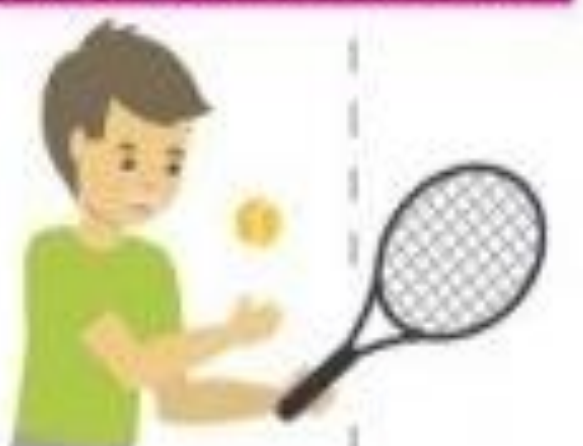




\section{El consumo nocivo de alcohol provoca}

$100 \%$ de los trastornos por consumo de alcohol

$18 \%$ de los suicidios

$27 \%$ de las lesiones de tránsito

$18 \%$ de la violencia

$13 \%$ de la epilepsia interpersonal

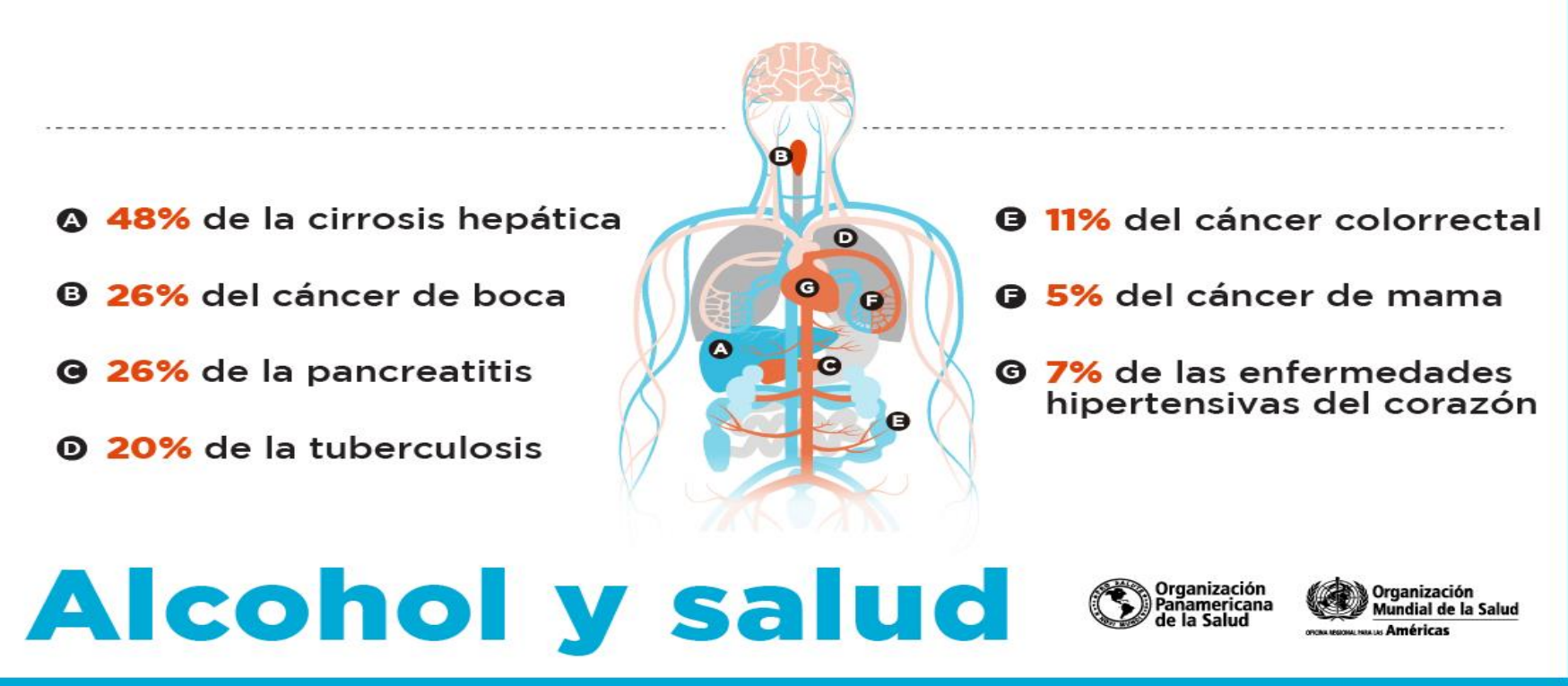




\section{DILE NO AL TABACO AHORA Y... ISIEMPRE!}

\section{Fumar te hace más vulnerable a la COVID-19}

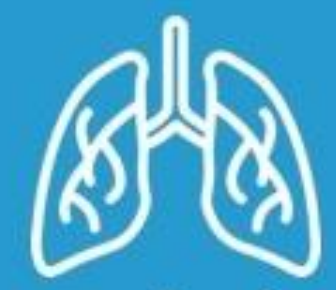

Tienes más riesgo de enfermar gravemente si tus pulmones no están saludables

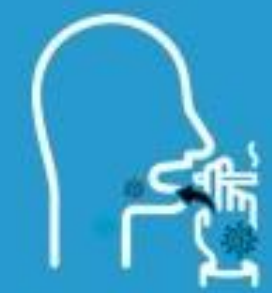

Aumenta el riesgo de transmisión de la mano a la boca
¿A qué estás esperando? ¡Deja de fumar y dale a tus pulmones una oportunidad! 


\section{¿Cómo pueden ayudar los familiares?}

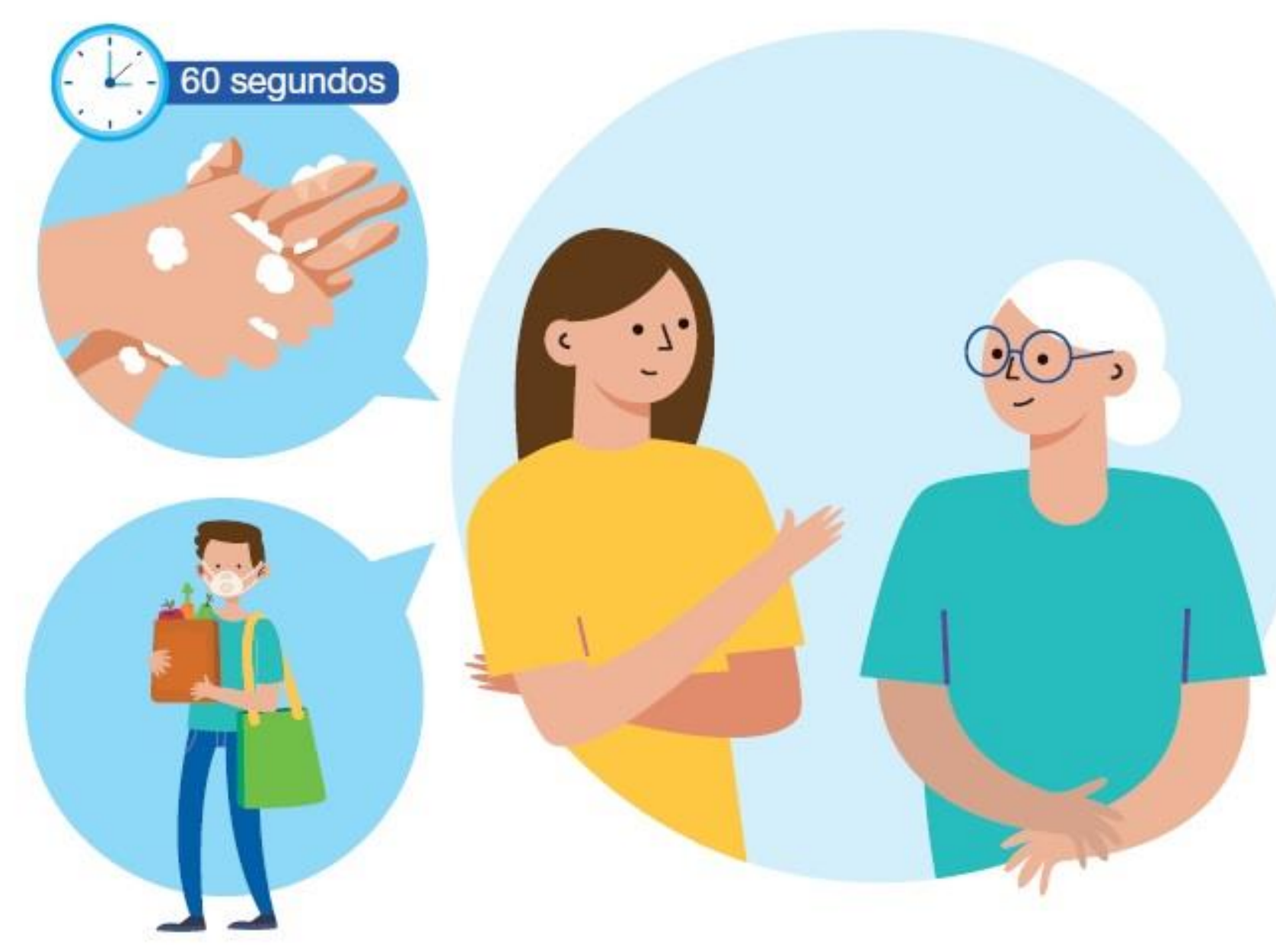

OPS (1) 


\section{¿Cómo pueden ayudar los familiares?}

- Hablar con su familiar, evalúe los riesgos.

Escúchelo, y explique las medidas de prevención

- Planificar las necesidades básicas como los alimentos, el agua y los medicamentos.

- Asegurarse de tener un suministro suficiente de todos sus medicamentos como mínimo para 90 días.

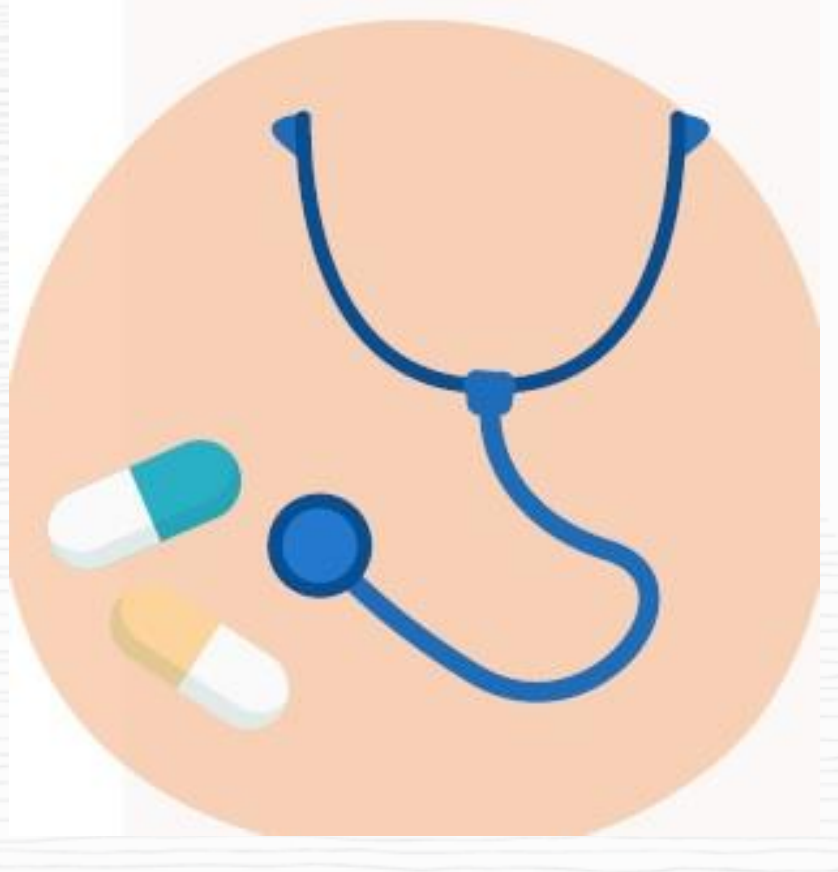




\section{¿Cómo pueden ayudar los familiares?}

- Apoyarle para que tenga una provisión suficiente de alimentos saludables.

- Ayudar para que se mantenga activo todos los

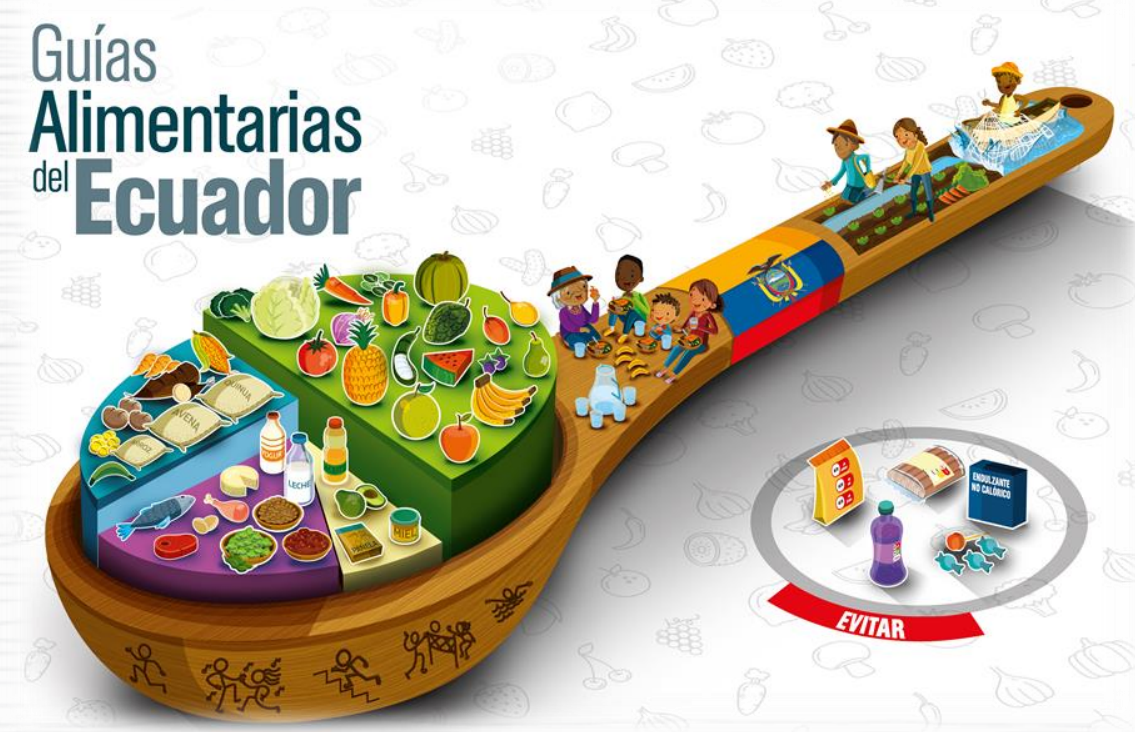

- Tener suministros de limpieza en el hogar (como jabón, desinfectantes y desinfectante de manos a base de alcohol). días a la persona con ECNT 


\section{¿Cómo pueden ayudar los familiares?}

- Insistir con el lavado de manos con agua y jabón constante por al menos 60 segundos, y con el uso de desinfectantes como alcohol en gel.

- Evitar que salgan para realizar compras u otras actividades para minimizar contacto social. Los acompañantes o responsables de los adultos mayores deben asegurarse de que estos tengan suministros suficientes, para varios días u semanas.

- Limitar las visitas de hijos, nietos, sobrinos, sobre todo si tienen algún síntoma respiratorio, es una medida quizás un poco dura pero con resultados efectivos. Mientras menos contacto con gente de afuera, menos el riesgo de contagio.

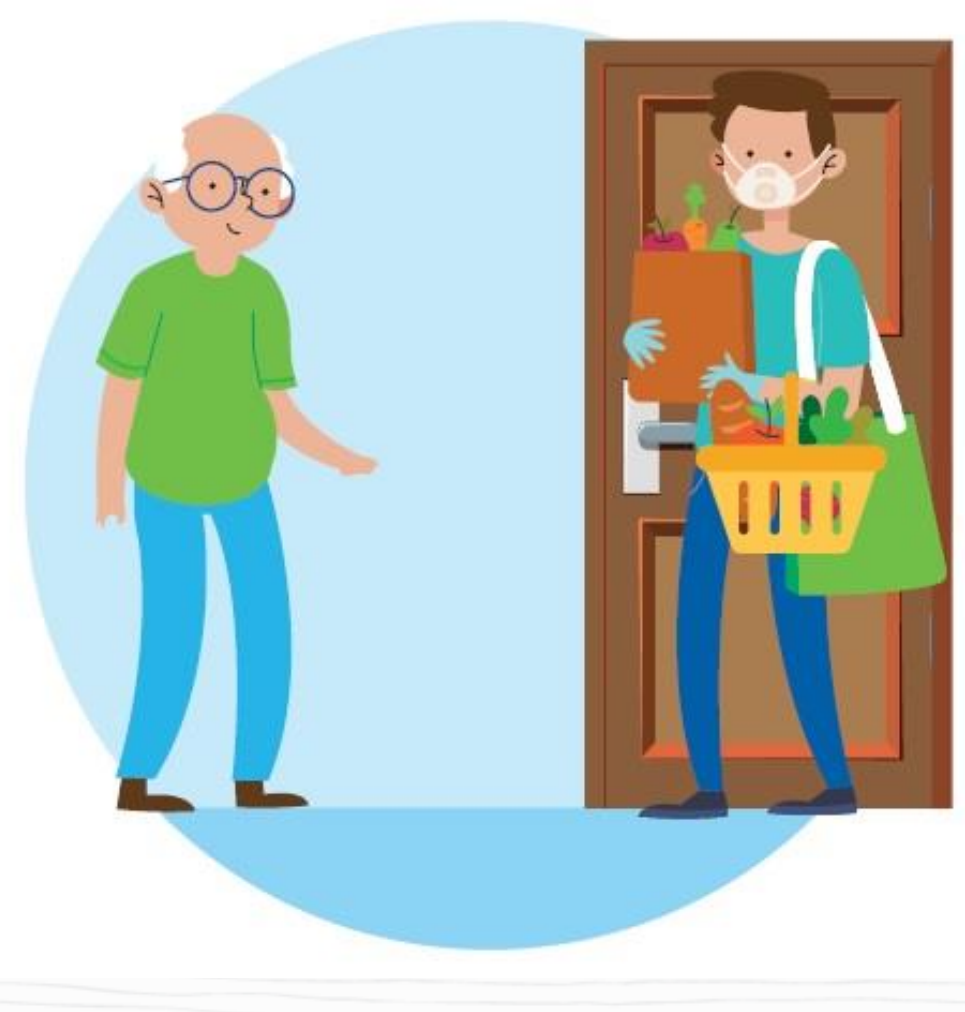




\section{¿Debo seguir tomando mis medicamentos habituales?}

- No comience ni interrumpa ninguna medicación sin hablar primero con su médico.

- Lo más importante es que tome sus medicamentos con la regularidad como se los hayan recetado.

- Asegúrese de no quedarse sin medicación con la misma frecuencia.

- En este momento no hay ninguna indicación de

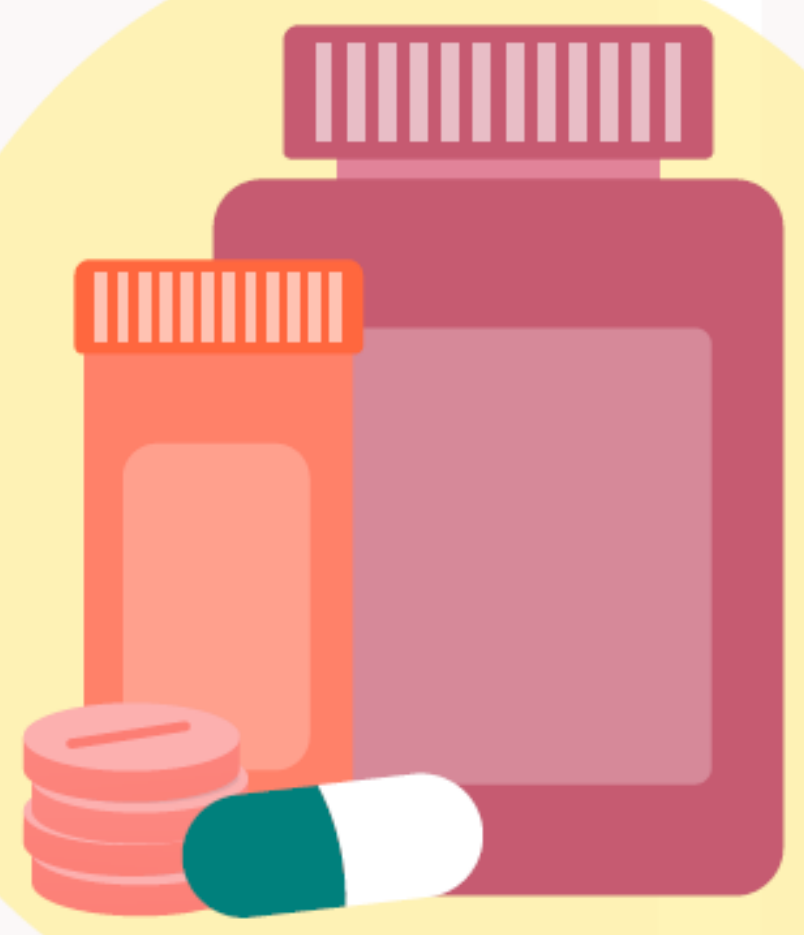
que se deba suspender algún medicamento si contrae la COVID-19. 


\section{¿Qué puedo hacer si siento estrés o ansiedad?}

Muchas personas con enfermedades crónicas ya tienen bastantes preocupaciones en mente y pueden tener depresión y ansiedad subyacentes. La pandemia de COVID-19 hace las cosas más difíciles. Sepa que no está solo.

Asegúrese de encontrar formas de hacer una pausa en las noticias sobre el coronavirus, así tendrá más espacio para pensar en su bienestar.

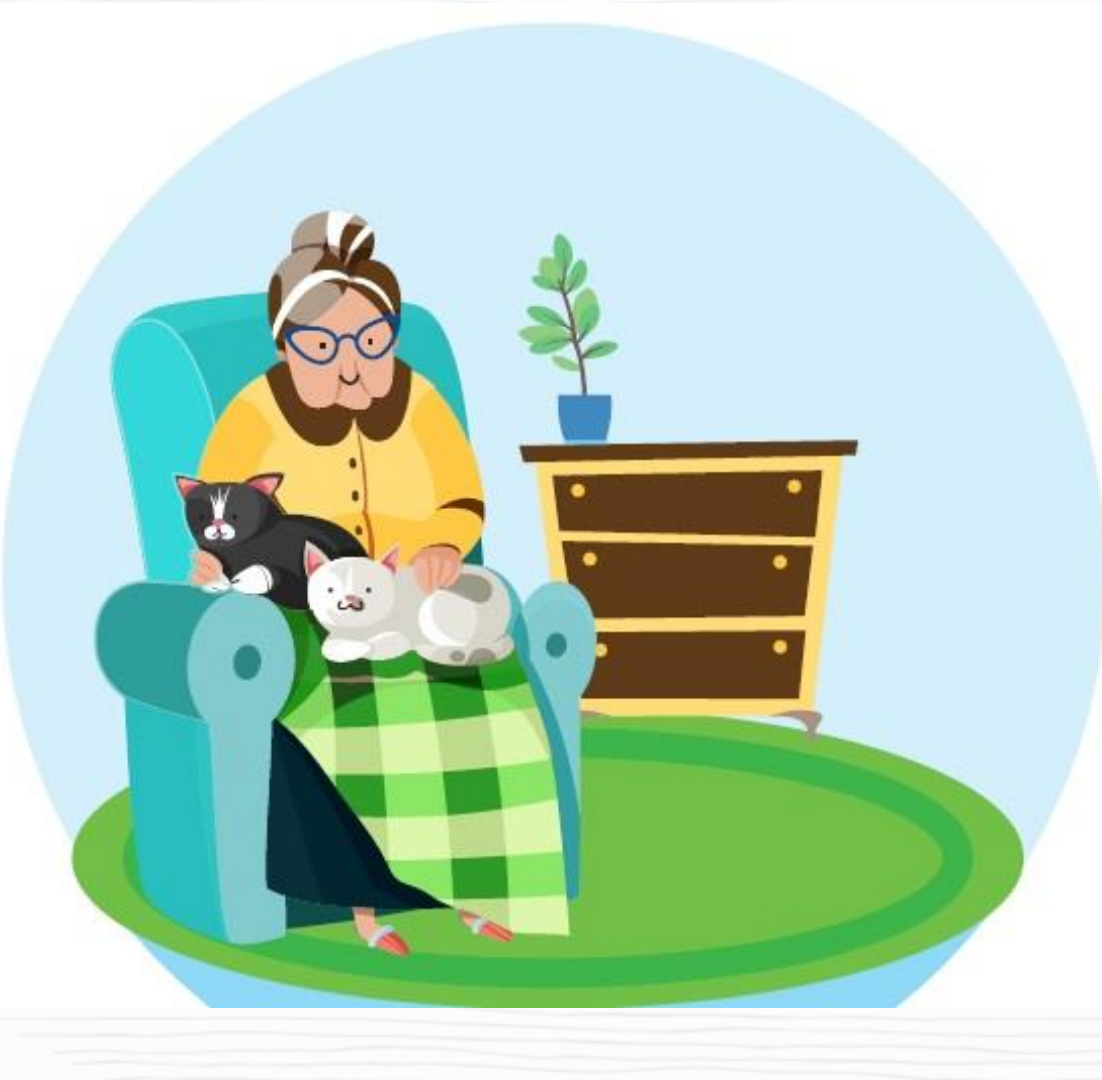




\section{¿Qué puedo hacer si siento estrés o ansiedad?}

- Permanezca en contacto con sus amigos y su familia. Llame a sus amigos y familiares con regularidad para conservar el vínculo social.

- Encuentre actividades que le ayuden a relajarse como leer, escuchar música o caminar.

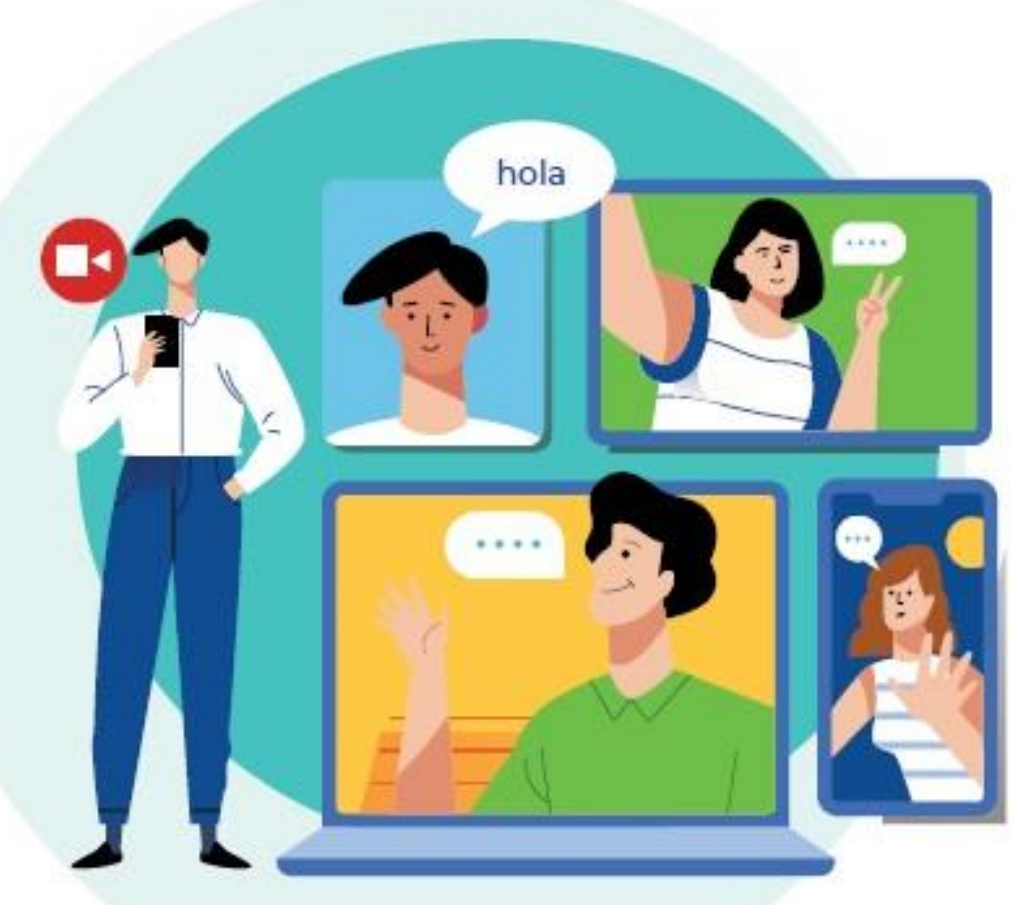

- Si se siente muy ansioso o deprimido, no dude en buscar ayuda: llame a un amigo o un familiar, o consulte a su médico. 


\section{Recursos disponibles}

\section{www.paho.org/coronavirus}

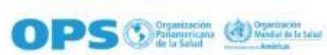

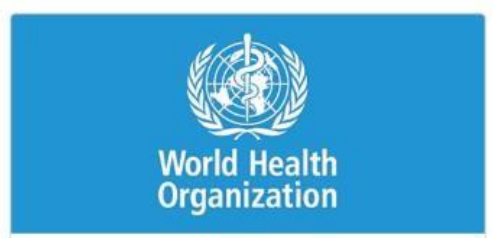

Website OMS COVID-19

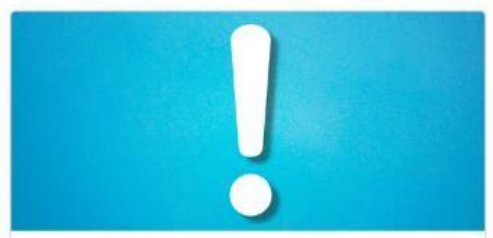

Alertas Epidemiológicas

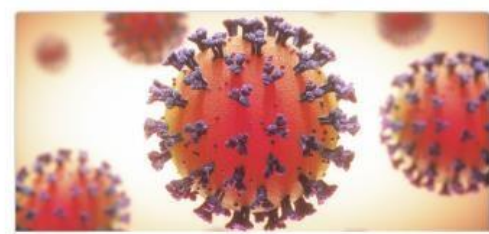

Guías Técnicas OMS

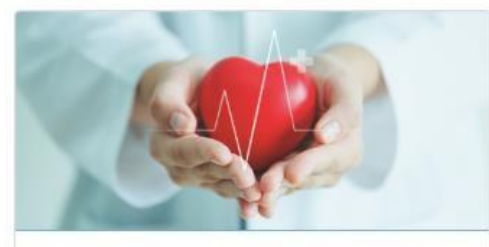

COVID-19 \& Temas de Salud

- temas palises recursos $\sim$ medios $\sim$ acercade $\backsim a$

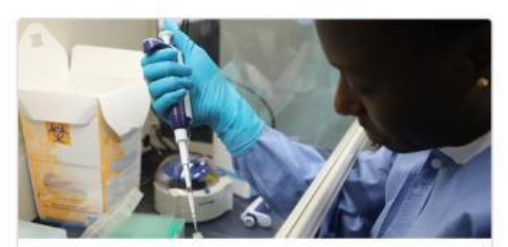

Documentos técnicos de la OPS

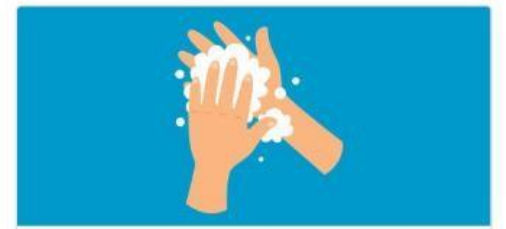

Material de comunicación

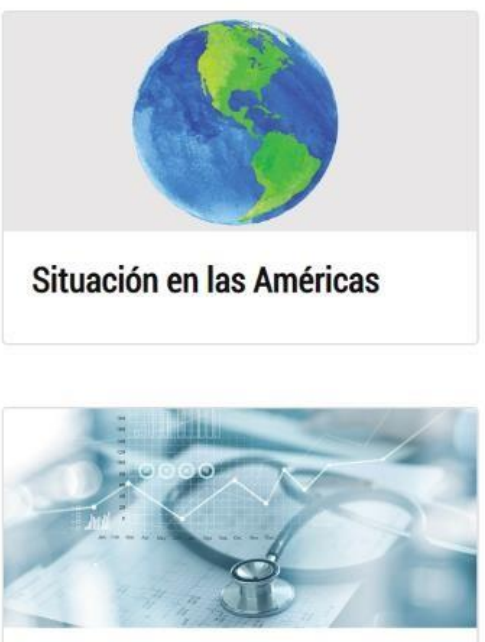

Portal de evidencia

OPS O) 


\section{Fuentes de información}

https://coronavirusecuador.com/

https://www.salud.gob.ec/el-ministerio-de-salud-publica-del-ecuadormsp-informa-situacion-coronavirus/

Secretaría de Gestión del Riesgo

Secretaría de Comunicación

Organización Panamericana de la Salud

www.paho.org 


\section{Experto solventa dudas}

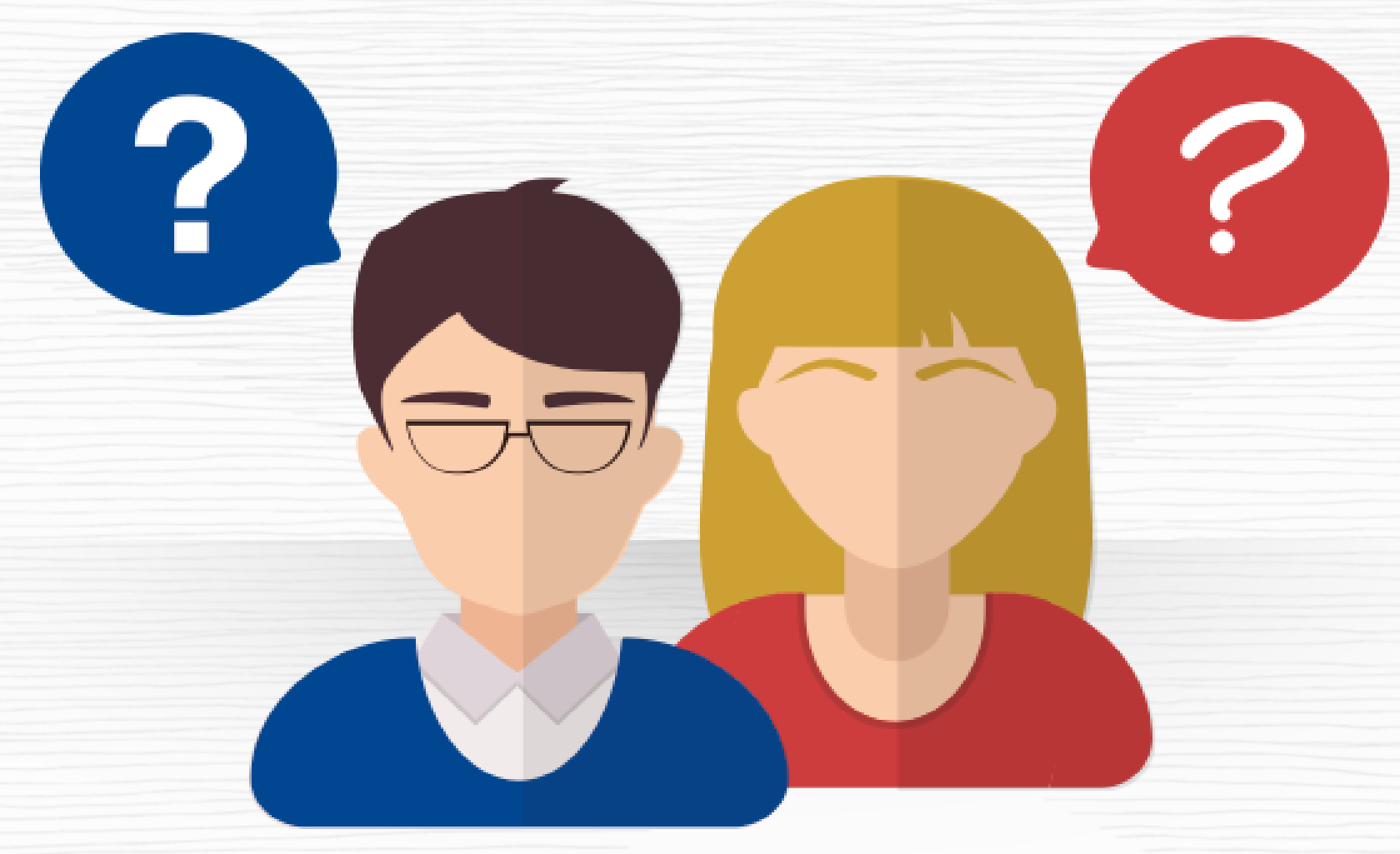


